\title{
UTJECAJ SPOLNE ZASTUPLJENOSTI U UPRAVLJAČKIM POZICIJAMA NA PROFITABILNOST VELIKIH PODUZEĆA U REPUBLICI HRVATSKOJ
}

\author{
Željko Mateljak \\ Dr. sc., docent, Ekonomski fakultet, Sveučilište u Splitu, Cvite Fiskovića 5, 21000 Split, Hrvatska; \\ e-mail: zeljko.mateljak@efst.hr
}

\begin{abstract}
SAŽETAK
Svako poduzeće nastoji organizirati svoje poslovanje primjerenim upravljačkim modelom koji se provodi kroz upravne organe u odnosu na trenutno poslovno okruženje. Temeljni upravni organi u mnogim poduzećima su skupština društva, upravni odbor i nadzorni odbor. Naglasak u ovom radu bio je na analizi spolne zastupljenosti u upravljačkim pozicijama odnosno postoji li razlika u ostvarivanju profitabilnosti kod velikih poduzeća u Republici Hrvatskoj u odnosu na zastupljenost žena i muškaraca u upravljačkim pozicijama. Predmet ovog rada je prepoznati važnost spolne zastupljenosti u upravljačkim pozicijama kod velikih poduzeća u Republici Hrvatskoj. Problem ovog rada je utvrditi na koji način spolna zastupljenost u upravljačkim pozicijama doprinosi postizanju veće profitabilnosti kod velikih poduzeća u Republici Hrvatskoj. Temeljna hipoteza rada je da postoji statistički značajna razlika između spolne zastupljenosti u upravljačkim pozicijama i profitabilnosti velikih poduzeća u Republici Hrvatskoj. Istraživanje se provodi na 148 velikih poduzeća iznad 600 zaposlenika u Republici Hrvatskoj. Rezultati istraživanja pokazali su da ne postoji statistički značajna razlika između profitabilnosti i spolne zastupljenosti u upravljačkim pozicijama kod velikih poduzeća iznad 600 zaposlenika u Republici Hrvatskoj. Ovo je istraživanje osnova za daljnja istraživanja na ovu temu u Republici Hrvatskoj.
\end{abstract}

Ključne riječi: spolna zastupljenost, upravljačke pozicije, velika poduzeća, profitabilnost

\section{UVOD}

Ravnopravnost spolova u svakoj državi je temelj demokratskih načela, ali i ustavnog poretka koji se temelji na sustavnoj primjeni rodne zastupljenosti u svim profitnimi/ili neprofitnim organizacijama. Osim demokratskih načela i ustavnog poretka, težnja ka uspostavljanju ravnopravne rodne zastupljenosti na svim razinama u društvu je pokazatelj zrelosti svakog društva. U posljednje vrijeme, ravnopravnost spolova je uvelike naglašena u upravljačkim pozicijama profitnih i/ili neprofitnih organizacija. Kod upravljačkih pozicija profitnih organizacija podrazumijevaju se 
organi društva poput uprave društva, nadzornog odbora, upravnog odbora i skupštine društva, dok se kod neprofitnih organizacija isto prvenstveno odnosi na rukovodstvo institucija, upravna i ostala vijeća.

U Republici Hrvatskoj je ravnopravnost spolova regulirano Zakonom o ravnopravnosti spolova kojeg donosi Vlada Republike Hrvatske preko Ureda za ravnopravnost spolova. Prvi Zakon o ravnopravnosti spolova donesen je 14. srpnja 2003. godine. Novi Zakon o ravnopravnosti spolova donesen je 2008. godine koji je objavljen u Narodnim novinama po brojem 82/08 čime je prestao važiti Zakon o ravnopravnosti spolova iz 2003. godine objavljen u Narodnim novinama pod brojem 116/03. Zakonom o ravnopravnosti spolova utvrđuju se opće osnove za zaštitu i promicanje ravnopravnosti spolova kao temeljne vrednote ustavnog poretka Republike Hrvatske, te se definira i uređuje način zaštite od diskriminacije na temelju spola i stvaranje jednakih mogućnosti za žene i muškarce (Narodne Novine, 82/08).

Pročišćeni tekst Zakona iz 2008. godine koji je donesen u 2017. godini također je objavljen u Narodnim novinama pod brojem 69/17. Prema ovoj verziji Zakona, ravnopravnost spolova znači da su žene i muškarci jednako prisutni u svim područjima javnog i privatnog života, da imaju jednak status, jednake mogućnosti za ostvarivanje svih prava, kao i jednaku korist od ostvarenih rezultata. Nadalje, prema Glavi IV, članku 13. definirana je zabrana diskriminacije na područjima zapošljavanja rada, i to u javnom i privatnom sektoru (Narodne Novine, 69/17).

U svom članku Veštić (2017) navodi razloge donošenja i institucionalne mehanizme osiguranja provedbe Zakona o ravnopravnosti spolova. Razlozi donošenja novog Zakona o ravnopravnosti spolova iz 2008. godine bila je Odluka Ustavnog suda kojom je Zakon o ravnopravnosti spolova iz 2003. ukinut, a kao datum njegova prestanka važenja je određen 15. srpnja 2008. Kako bi postojao kontinuitet u zakonskoj regulaciji ravnopravnosti spolova, pripremljen je novi Zakon o ravnopravnosti spolova, koji je donesen po hitnom postupku. Isti je donesen, objavljen i stupio je na snagu na dan prestanka važenja ranijeg Zakon o ravnopravnosti spolova. U Nacionalnoj politici za ravnopravnost spolova, za razdoblje od 2011. do 2015., u odnosu na Zakon o ravnopravnosti spolova iz2008. navedeno je kako je isti dodatno usklađen s odredbama međunarodnih standarda kao i s pravom Europske unije te kako je njegovo donošenje bilo jedno od važnih mjerila za zatvaranje pregovaračkog poglavlja 19. Socijalne politike i zapošljavanja. U odnosu na pomake koji su ostvareni donošenjem Zakona o ravnopravnosti spolova iz 2008. navodi se kako je Zakon proširio osnove zabrane diskriminacije u području zapošljavanja i rada, uveo sustav kvota za izbore na svim razinama, unaprijedio područje sudske zaštite od diskriminacije i ustanovio nezavisno tijelo za suzbijanje diskriminacije u području ravnopravnosti spolova čime su se redefinirale i proširile ovlasti i djelokrug rada pravobraniteljice za ravnopravnost spolova sukladno obvezama u preuzimanju pravne stečevine Europske unije. Zakonski je prvi put pravno definirana uloga i status županijskih povjerenstava za ravnopravnost spolova kao tijela zaduženih za provedbu Zakona o ravnopravnosti spolova uz pravobraniteljstvo, Ured za ravnopravnost spolova Vlade Republike Hrvatske i koordinatore i koordinatorice u tijelima državne uprave. Uz razloge donošenja, u radu su navedeni također i institucionalni mehanizmi osiguranja provedbe u koje spada Ured za ravnopravnost poslova, Pravobranitelj/ica za ravnopravnost spolova, Koordinatori/ice u tijelima državne uprave te Povjerenstva za ravnopravnost spolova. 
Na temelju prethodno iznesenih činjenica, sa sigurnošću se može potvrditi da su donošenjem Zakona o ravnopravnosti spolova, uz Ustav Republike Hrvatske, stvorene pretpostavke za postizanja uravnoteženosti muškaraca i žena na svim društvenim razinama, a za potrebe ovog rada posebno važnih upravljačkih pozicija. Stoga je naglasak u ovom radu na analizi spolne zastupljenosti u upravnim organima odnosno postoji li razlika u ostvarivanju profitabilnosti u velikim poduzećima u Republici Hrvatskoj u odnosu na zastupljenost žena i muškaraca u upravljačkim pozicijama. Predmet ovog rada je prepoznati važnost spolne zastupljenosti u upravljačkim pozicijama kod velikih poduzeća u Republici Hrvatskoj. Problem ovog rada je na koji način spolna zastupljenost u upravljačkim pozicijama doprinosi postizanju profitabilnosti kod velikih poduzeća u Republici Hrvatskoj. Temeljna hipoteza rada je da postoji statistički značajna razlika između profitabilnosti poduzeća i spolne zastupljenosti u upravljačkim pozicijama kod velikih poduzeća u Republici Hrvatskoj. Također je bitno naglasiti da će se zastupljenost spola u upravljačkim pozicijama utvrditi analizom nad 148 velikih poduzeća ${ }^{1}$ iznad 600 zaposlenika iz sudskog registra i financijskog portala Prima Bon u Republici Hrvatskoj, dok će se profitabilnost istih poduzeća mjeriti pokazateljima EBITDA marže ${ }^{2}$ (engl. Earnings before interest, taxes, depreciation and amortization) i neto profitne marže ${ }^{3}$. Izvorni podaci za utvrđivanje profitabilnosti poslovanja putem prethodno navedenih pokazatelja koristit će se iz objavljenih temeljnih financijskih izvještaja za 2018. godinu.

\section{PRETHODNA ISTRAŽıIVANJA}

Nakon navođenja pojma i pravne regulative područja ravnopravnosti spolova te temeljnih smjernica rada u nastavku rada dat će se pregled od sada provedenih relevantnih istraživanja. Tako Buble (Buble, 2006) u svojoj knjizi prilikom objašnjavanja suvremenih stilova vodstva navodi da interaktivni stil vodstva smatra da žene imaju drugačiji stil vodstva od muškaraca, točnije stil vođenja koji je efikasniji u suvremenoj turbulentnoj okolini poduzeća. lako žene često imaju iste osobine, sklonije su interaktivnom ponašanju. Interaktivni vođa je sklon konsenzusu i participaciji. Međutim, interaktivni stil vođenja nije karakterističan samo za žene, mnogi muškarci su isto tako skloni interaktivnom ponašanju.

Nadalje, Pravobraniteljica za ravnopravnost spolova Republike Hrvatske u 2011. godini provela je istraživanje o podzastupljenosti žena na rukovodećim pozicijama nad 500 najvećih i najuspješnijih trgovačkih društava u Republici Hrvatskoj. Istraživanje je provedeno anketnim upitnikom. Stopa povrata je bila $85,6 \%$. Rezultati istraživanja su pokazali da su žene značajno, a često i izrazito, podzastupljene na rukovodećim pozicijama koje su uključivale vrhovni, srednji i niži menadžment. Ova tvrdnja nalazi potvrdu i u podacima o podzastupljenosti žena u upravljačkim tijelima (uprava, nadzorni odbor, upravni odbor). Osim na rukovodećim pozicijama, ovo istraživanje također pokazuje i podzastupljenost žena u upravljačkim i nadzornim tijelima. Od ukupno 928 članova uprava poslovnih subjekata koji su sudjelovali u istraživanju njih 751 je muškog spola što čini čak

1 Prema članku 5., stavka 5. Zakona o računovodstvu, velika poduzeća su ona poduzeća koja prelaze najmanje dva od tri sljedeća uvjeta, i to: ako imaju ukupnu aktivu veću od $150.000 .000,00$ kuna i prihod veći od 300.000.000,00 kuna te ako im je prosječan broj radnika tijekom poslovne godine veći od 250.

2 EBITDA-dobit prije kamata, poreza, deprecijacije i amortizacije. EBITDA marža se izračunava: (dobit prije kamata, poreza i amortizacije/poslovni prihodi)*100.

3 Neto profitna marža - (dobiti nakon oporezivanja/prihodi od prodaje)*100 
$81 \%$ svih članova uprava, dok žene čine tek $19 \%$ članica uprava (177 žena). Gotovo isto je u članstvu nadzornih odbora. Od ukupno 1.202 člana nadzornih odbora, muškarci drže 80 \% (963 člana nadzornog odbora), a žene tek 20 \% (239 članica nadzornih odbora). Nadalje, muškarci predstavljaju većinu svih članova/ica uprave u $83 \%$ poslovnih subjekata koji su sudjelovali u istraživanju, u $9 \%$ svih uprava postignuta je uravnotežena zastupljenost, dok su u $8 \%$ uprava žene u većini. Slično je i kod nadzornih odbora. U 89 \% svih nadzornih odbora većinu članova čine muškarci, žene čine većinu u 10 $\%$ svih nadzornih odbora, a u samo $1 \%$ nadzornih odbora je postignuta uravnotežena zastupljenost. Podaci su još više poražavajući što se tiče sudjelovanja žena na čelnim pozicijama. U $91 \%$ svih uprava na čelu uprave se nalazi muškarac, dok je u $9 \%$ njih na čelu uprave žena. U 89 \% nadzornih odbora na čelu se nalazi muškarac, a u tek 11 \% njih je na čelu žena (Izvještaj o radu Pravobraniteljice za ravnopravnost spolova Republike Hrvatske, 2011).

Pravobraniteljica za ravnopravnost poslova Republike Hrvatske je također u okviru Progress projekta „Uklanjanje staklenog labirinta - jednakost prilika u pristupu pozicijama ekonomskog odlučivanja“ provela kvantitativno istraživanje o zastupljenost žena i muškaraca u upravljačkim pozicijama u poslovnim subjektima na hrvatskom tržištu. Istraživanje je provedeno nad 500 trgovačkih društava prema prihodima s rang liste Fine iz 2012. godine primjenom elektronskog upitnika. Stopa povrata je bila 36,20\%. Rezultati istraživanja su pokazali da su žene izuzetno podzastupljene u upravljačkim tijelima istraživanih trgovačkih društava na hrvatskom tržištu, i to u tijelima upravljačke razine (uprava, upravni odbor i nadzorni odbor) u 2014. godini udio žena je bio 24,25 \%, a udio muškaraca 75,75 \%. Nadalje, u upravnim tijelima (uprava ili upravni odbor) društava koja su sudjelovala u istraživanju žene čine $25,40 \%$, a muškarci $74,60 \%$ svih članova uprave. U nadzornim odborima društava koja su sudjelovala u istraživanju, žene čine $22,66 \%$, a muškarci $77,34 \%$ svih članova. Uz prethodno navedene rezultate istraživanja, isto istraživanje je pokazalo da sudjelovanje žena u tijelima upravljačke razine vezano uz pravni oblik (zastupljenost žena u upravnim i nadzornim odborima je bolja u društvima s ograničenom odgovornošću nego u dioničkim društvima) i da zastupljenost žena i muškaraca na najvišim mjestima upravljanja ovisi o važnosti pozicije (žene su izuzetno podzastupljene na najvišim pozicijama ekonomskog upravljanja kao što su predsjednik uprave i nadzornih odbora) (Izvještaj o radu Pravobraniteljice za ravnopravnost spolova Republike Hrvatske, 2014).

Pravobraniteljica za ravnopravnost spolova je u svojem Izvješću za 2015. godinu provela analizu o zastupljenosti žena i muškaraca na upravljačkim pozicijama u sustavu državne uprave. 4 Istraživanje je provela pregledom internetskih stanica tijela državne uprave gdje je utvrđeno da se spolno razlučeni podaci o dužnosnicima i dužnosnicama te rukovodećim državnim službenicima i službenicama ne vode na način da su statistički, odnosno brojčano izraženi, već da u pravilu sva tijela državne uprave

4 Prema čl. 4. Zakona o sustavu državne uprave tijela državne uprave su ministarstva i državne upravne organizacije. Prema članku 45. Zakonu o sustavu državne uprave i prema članku 74a. Zakonu o državnim službenicima državni dužnosnici/e u tijelima državne uprave su ministri/ce, zamjenici/e ministra/ica, pomoćnici/ce ministra, predstojnici/ ce državnih ureda i ravnatelji/ce državnih upravnih organizacija. Rukovodeći državni službenici/e su zamjenici/e predstojnika/ce državnog ureda, glavni tajnici/e ministarstva i državnog ureda, zamjenici/e ravnatelja/ca državnih upravnih organizacija, ravnatelji/ce ureda Vlade Republike Hrvatske, predstojnik/ca Ureda potpredsjednika/ ce Vlade Republike Hrvatske, ravnatelji/ce ureda, agencija, direkcija i drugih stručnih službi koje Vlada Republike Hrvatske osniva uredbom te predstojnici/e ureda državne uprave u jedinicama područne (regionalne) samouprave. Rukovodeće državne službenike/ce imenuje i razrješava Vlada Republike Hrvatske, na temelju javnoga natječaja, ako zakonom nije drugačije određeno. 
na svojim stranicama imaju istaknute osobe koje se trenutno nalaze u vrhu upravljačke hijerarhije. Rezultati istraživanja su pokazali da unatoč ukupnom omjeru $40 \%$ - $60 \%$, u skladu s općim trendom na tržištu rada uočljiva je vertikalna segregacija po spolu: što je veća hijerarhijska razina, udio žena opada. U usporedbi s 40 \% žena u ukupnom broju državnih dužnosnika/ca u tijelima državne uprave, samo 21 \% žena se nalazi na poziciji čelnice tijela državne uprave (Izvještaj o radu Pravobraniteljice za ravnopravnost spolova Republike Hrvatske, 2015).

U svom Izvješću o radu Pravobraniteljica za ravnopravnost spolova je također istraživala zastupljenost žena u upravljačkim strukturama u sportu. Rezultati su pokazali da jedan od vidova neravnopravnosti žena u području sporta je njihova osjetna podzastupljenost u upravljačkim tijelima, odnosno tijelima odlučivanja. Taj problem je prisutan u sportskim ustanovama na svim razinama: lokalnoj, državnoj, europskoj i svjetskoj, a proizlazi iz strukturalne diskriminacije uvjetovane tradicionalnom rodnom ulogom žene za koju nije „prikladno“ da iskazuje interes za sportom ili se bavi njime u istim obimu kao muškarci (Izvještaj o radu Pravobraniteljice za ravnopravnost spolova Republike Hrvatske, 2017).

Prema objavljenom stručnom članku u poslovnom tjedniku Lider (https://lider.media/lider-trend/ samo-202-godine-su-potrebne-da-se-izjednaci-ekonomski-jaz-izmedu-zena-imuskaraca/, 4. 7. 2019. godine), Svjetski ekonomski forum je, prema trenutačnim stopama gospodarskog razvoja država, procijenio kako će trebati najmanje još 202 godine da se ekonomski jaz između muškaraca i žena, utemeljen isključivo na spolnoj razlici, izjednači na globalnoj razini. I dok postoji pretpostavka da su najrazvijenije svjetske ekonomije ujedno i najnaprednije u poticanju ravnopravnosti spolova, napose u poduzetništvu, rezultati istraživanja Vijeća za inozemne odnose, američke nevladine organizacije sa sjedištem u New Yorku, stavilo je države kao što su Meksiko, Salvador, ali i Hrvatsku kao one koje danas nude ženama u odnosu na muškarce, veću jednakost u gospodarskim odnosima nego što je slučaj u ekonomskim najjačim globalnim silama kao što su SAD, Njemačka ili Norveška.

U svom istraživanju Posarić, Kokot i Klačmer Čalopa (Posarić, Kokot i Klačmer Čalopa, 2017) analiziraju zastupljenost žena na upravljačkim pozicijama u hrvatskim poduzećima i njihov utjecaj na uspješnost poslovanja. Istraživanje je provedeno među 383 najveća hrvatska poduzeća iz 2013. godine prema kriteriju najvećih ostvarenih prihoda. Bitno je naglasiti da od 383 istraživana poduzeća, njih 379 koristi dvorazinski model korporativnog upravljanja. Rezultati istraživanja su pokazali da je u 379 promatranih poduzeća 829 članova uprave te 1152 članova nadzornog odbora. Od ukupno 829 članova uprave, 128 je članica što čini tek $15 \%$ žena u upravama promatranih poduzeća. Udio žena u nadzornim odborima iznosi $21 \%$, točnije od 1152 člana nadzornih odbora promatranih poduzeća, 240 je članica. Ova analiza pokazuje da je udio žena na upravljačkim pozicijama kod 400 najvećih hrvatskih poduzeća manji od $40 \%$, a 40 \% žena u upravnim odborima je preporuka Europske komisije na temelju koje je izražen i prijedlog direktive u 2013. godini. Od ukupno promatranih 379 poduzeća, njih 128 (15\%) u upravi ima jednu ili više žena. Nadalje, istraživanje je pokazalo da poduzeća koja imaju barem jednu ženu u upravi imaju veću prosječnu dobit nakon oporezivanja u odnosu na poduzeća koja nemaju niti jednu ženu u upravi te kako poduzeća koja imaju barem jednu ženu u nadzornom odboru imaju veću prosječnu dobit nakon oporezivanja u odnosu na poduzeća koja nemaju u nadzornom odboru ženu. $U$ ova dva rezultata istraživanja primijenjen je Pearsonov koeficijent korelacije i ispitana je statistička značajnost t-testom. Rezultati su pokazali da je u oba slučaja dobivena slaba pozitivna veza $(0,065027$ i 0,078599$)$. Što se tiče statističke značajnosti 
utvrđeno je da ne postoji statistički značajna razlika $(p=0,244 ; p>0,05)$ između uprava sa samo članovima muškog spola i uprava s članovima muškog i ženskog spola s obzirom na dobit nakon oporezivanja te da postoji statistički značajna razlika $(p=0,000 ; p<0,05)$ između nadzornih odbora sa samo članovima muškog spola i nadzornih odbora s članovima muškog i ženskog spola s obzirom na dobit nakon oporezivanja. Detaljnije, prethodno znači da se ne može sa sigurnošću tvrditi da spolna raznolikost u upravi i nadzornom odboru doprinosi uspješnosti promatranih poduzeća.

Nidogon Višnjići ostali (Nidogon Višnići ostali, 2018), su proveli istraživanje o stavovima i percepcijama žena na rukovodećim pozicijama o njihovom položaju na radnom mjestu nad 112 ispitanica koristeći elektroničko slanje anketnog upitnika ispitanicama koje su zaposlene na rukovodećim pozicijama u poslovnim organizacijama u Republici Hrvatskoj. Rezultati istraživanja su pokazali da je zastupljenost žena u Republici Hrvatskoj na upravljačkim pozicijama $19 \%$, a prosjek u Europskoj uniji je 20,2 \%, da poslovne organizacije koje imaju veći udio žena u menadžmentu ostvaruju $35 \%$ veći povrat kapitala, $26 \%$ više cijene dionica, i imaju rast neto profita od $14 \%$ u odnosu na one organizacije bez žena u upravi koje ostvaruju $10 \%$ rast neto profita.

Soldat (Soldat, 2018) u svom radu analizira odnos broja rukovoditelja žena i muškaraca u Europskoj uniji gdje naglašava da je udio muškaraca rukovoditelja $67 \%$, a žena $33 \%$. Što se tiče Republike Hrvatske, udio žena menadžera je na razini $30 \%$.

Nadalje, Credit Suisse Research institut je 2014. godine proveo istraživanja na temu spolne raznolikosti na uzorku od 27.000 direktora među 42 zemlje i njihov utjecaj na uspješnost istraživanih poduzeća. Rezultati istraživanja su pokazali da broj žena na rukovodećim pozicijama raste. Točnije, među istraživanim zemljama prosječna zastupljenost žena 2010. godine u odborima je iznosila $9,6 \%$, a u 2013. godini 12,7 \%. Rezultati istraživanja su također pokazali da poduzeća kod kojih se žena nalazi na funkciji izvršnog direktora ostvaruju $28 \%$ veću stopu povrata na kapital, $6 \%$ veći odnos duga i glavnice i 11 \% veći odnos isplate dividendi od poduzeća koja imaju muškarce na funkciji izvršenog direktora. Poduzeća koja imaju više od 10 \% žena na funkciji izvršnog direktora i operativnog menadžera ostvaruju $27 \%$ veću stopu povrata na kapital, $26 \%$ veći odnos duga i glavnice i $42 \%$ veći odnos isplate dividendi od poduzeća koja imaju manje od $5 \%$ žena na funkciji izvršnog direktora i operativnog menadžera. Poduzeća koja imaju više od $15 \%$ žena na funkciji višeg menadžmenta ostvaruju $52 \%$ veću stopu povrata na kapital, $61 \%$ veći odnos duga i glavnice i $22 \%$ veći odnos isplate dividendi od poduzeća koja imaju manje od $10 \%$ žena na funkciji višeg menadžmenta (https:// www.credit-suisse.com/about-us-news/en/articles/media-releases/csri-gender-3000-201609. html?t=183_0.5562689241064736, 21. 7.2019.).

Tvrtka McKinsey \& Company, (McKinsey \& Company, 2007), je provela istraživanje pod nazivom „Žene su bitne“" (engl. Women Matters) nad 89 europskih poduzeća na temu udjela žena u odboru direktora te njihova funkcija u poduzeću. Rezultati istraživanja su pokazali da poduzeća s većim raznolikošću žena na rukovodećim pozicijama ostvaruju veću stopu povrata na vlastiti kapital od prosjeka industrije (11,40\% naspram 10,30\%), da ostvaruju veću operativnu dobit od prosjeka industrije $(11,10 \%$ naspram $5,80 \%)$ i ostvaruju rast cijena dionica od prosjeka industrije (64 \% naspram $47 \%)$. 
Europska komisija je 2014. godine, (https://ec.europa.eu/info/policies/justice-and-fundamentalrights/gender-equality, 21. 7. 2019.) provela istraživanje među 28 zemalja članica Europske unije nad 613 poduzeća koje su prisutne na burzama među kojima je naravno i Republika Hrvatska. Analiza rezultata istraživanja je obuhvatila spolnu zastupljenost kod funkcije predsjednika upravnog odbora ili nadzornog odbora u dvorazinskom modelu i članova upravnog odbora ili nadzornog odbora u dvorazinskom modelu. Rezultati istraživanja su pokazali da je na nivou cijele Europske unije prosječni udio od 7 \% žena i 93 \% muškaraca odnosi na funkciju predsjednika upravnog odbora ili nadzornog odbora u dvorazinskom modelu te da se prosječni udio od $20 \%$ žena i 80 \% muškaraca odnosi na članstvo upravnog odbora ili nadzornog odbora u dvorazinskom modelu. Što se tiče podataka za Republiku Hrvatsku rezultati istraživanja, nad 25 poduzeća, su pokazali da je prosječni udio od 12 \% žena i 88 \% muškaraca odnosi na funkciju predsjednika upravnog odbora ili nadzornog odbora u dvorazinskom modelu te da se prosječni udio od $19 \%$ žena i 81 \% muškaraca odnosi na članstvo u upravnom odboru ili nadzornom odboru u dvorazinskom modelu.

Joy i ostali su proveli istraživanje 500 poduzeća s Fortune liste unutar kojeg su istraživali zastupljenost žena i njihova povezanost s uspješnosti poduzeća mjerene povratom na prodaju, povratom na vlastiti kapital i povratom na investirani kapital. Rezultati istraživanja su pokazali da poduzeća s većom zastupljenosti žena u odborima ostvaruju $42 \%$ veći povrat na prodaju, $53 \%$ veći povrat uloženog vlastitog kapitala i $66 \%$ veći povrat investiranog kapitala. (https://www.catalyst.org/wpcontent/ uploads/2019/01/The_Bottom_Line_Corporate_Performance_and_Womens_Representation_ on_Boards.pdf, 21. 7.2019.).

Suprotno prethodno navedenim istraživanjima, autori Tacheva i Huse (Tacheva, Huse, 2006) su proveli istraživanje nad 249 norveških poduzeća na temu povezanosti zastupljenosti žena i efektivnosti poduzeća. Rezultati istraživanja su pokazali da postoji negativna povezanost između zastupljenosti žena u nadzornim odborima i uspješnosti financijske kontrole odbora nad poduzećima. Uz to, postoji pozitivan odnos između zastupljenosti žena u nadzornim odborima i djelotvornosti istih odbora u obavljanju kvalitetne funkcije kontrole nad poduzećem. Točnije, istraživanjem se zaključilo da zastupljenost žena u nadzornim odborima može imati pozitivan i negativan utjecaj na poduzeće te da imaju bolje rezultate kontrole nad zadacima kvalitativne prirode, dok imaju niže sposobnosti kontrole nad uslužnim zadacima. Provedeno istraživanje pokazuje da zastupljenost žene neće uvijek doprinijeti povećanju uspješnosti poduzeća ukoliko se nalaze u nadzornim odboru. Ovom istraživanju se može dodati i istraživanje provedeno od strane Mkhize i Mswelija (Mkhize, Mswelija 2010) koje je provedeno u Južnoafričkoj Republici u kojem je utvrđeno da poduzeća kojima upravljaju žene ne nadmašuju rezultate poduzeća kojima upravljaju muškarci te istraživanje Strelcove (Strelcova, 2004) koje pokazuje da nema značajne statističke razlike između cijena dionica i performansi poduzeća koja imaju na poziciji glavnog izvršnog direktora ženu i onih gdje ulogu glavnog izvršnog direktora obavlja muškarac.

Nakon prethodno prikazanih provedenih rezultata istraživanja iz područja zastupljenosti žena i muškaraca u upravljačkim pozicijama, u nastavku rada prikazat će se rezultati provedenog istraživanja. 


\section{REZULATI ISTRAŽIVANJA}

\section{1 Metodologija istraživanja}

Istraživanje utjecaja spolne zastupljenosti u upravljačkim pozicijama na profitabilnost poduzeća u Republici Hrvatskoj provedeno je među velikim poduzećima prema kriteriju broja zaposlenih. U uzorak su izabrana velika poduzeća iznad 600 zaposlenika. Istraživanje je provedeno nad 148 velikih poduzeća temeljem popisa iz 2018. godine dobivenog od financijskog portala Prima Bon u razdoblju od 15. 7. 2019. do 15. 8. 2019. godine, i to 71 veliko poduzeće iznad 1000 zaposlenika i 77 velikih poduzeća između 600 i 1000 zaposlenika.

Obrada podataka je napravljena metodom prikupljanja podataka o spolnoj zastupljenosti u upravljačkim pozicijama pojedinačno za svako istraživano poduzeće analizom podataka iz Sudskog registra Ministarstva pravosuđa i s financijskog portala Prima bon. Uz navedenu metodu, u radu je korištena deskriptivna statistika za potrebe prikazivanja rezultata istraživanja za osnovne karakteristike uzorka te Mann Whitney-ev test za ispitivanje statističke značajnosti testa.

Obrađeni podaci koristili su se za prihvaćanje ili odbijanje temeljne hipoteze rada. Kako je već navedeno, istraživanjeje obuhvatilo spolnu zastupljenost u upravnim odborima kod jednorazinskog modela upravljanja i/ili upravi društva i nadzornim odborima u dvorazinskom modelu upravljanja. $S$ druge strane, za mjerenje profitabilnosti korišteni su pokazatelji EBITDA marža (engl. Earnings before interest, taxes, depreciation and amortization) i neto profitna marža. Za izračun prethodno navedenih pokazatelja korišteni su obvezni financijski izvještaji, račun dobiti i gubitka te bilanca, objavljeni na internet stranici FINE te na financijskom portalu Prima Bon za 2018. godinu.

\section{2 Osnovne karakteristike uzorka}

Prije prikazivanja rezultata temeljne hipoteze istraživanja, dat će se pregled pravnih oblika istraživanih poduzeća. Poduzeća obuhvaćena ovim istraživanjem analizirana su prema dva pravna oblika, i to dioničko društvo te društvo s ograničenom odgovornošću. Rezultati istraživanja analiziranih poduzeća prema pravnim oblicima prikazani su u tablici 1.

Tablica 1. Velika poduzeća iznad 600 zaposlenika

\begin{tabular}{|l|c|c|}
\hline PRAVNI OBLICI & BROJ & UDIO (\%) \\
\hline Dioničko društvo & 50 & 33,78 \\
\hline Društvo s ograničenom odgovornošću & 92 & 62,16 \\
\hline Ostali oblici & 6 & 4,06 \\
\hline UKUPNO & 148 & 100,00 \\
\hline
\end{tabular}

Izvor: izrada autora

Tablica 1 prikazuje da od ukupno 148 velikih poduzeća iznad 600 zaposlenika analiziranih u ovom istraživanju postoji 50 poduzeća ili 33,78 \% koja su dionička društva, dok 92 poduzeća ili $62,16 \%$ su društva s ograničenom odgovornošću. $U$ ostale oblike društva spada 6 poduzeća $(4,06 \%)$ koja 
pripadaju ostalim pravnim oblicima društva, kao što su 3 komanditna društva, 2 pravne osobe za koju je upis propisan zakonom i 1 javna ustanova.

\section{3 Analiza utjecaja spolne zastupljenosti u upravljačkim pozicijama na profitabilnost poduzeća u Republici Hrvatskoj}

Kao što je prethodno naglašeno, u ovom radu provelo se istraživanje u svrhu analize spolne zastupljenosti u upravljačkim pozicijama i njenog utjecaja na profitabilnost 148 velikih poduzeća iznad 600 zaposlenika u Republici Hrvatskoj. Prilikom provođenja analize spolne zastupljenosti u upravljačkim pozicijama korišten je jednorazinski i dvorazinski model upravljanja. Kod jednorazinskog modela upravljanja ispitanajespolnazastupljenost u upravnim odborima poduzeća, a kod dvorazinskog modela upravljanja ispitana je spolna zastupljenost u upravama poduzeća i nadzornim odborima. Kod oba modela je također utvrđena spolna zastupljenost kroz članstvo u navedenim upravljačkim organima, kao i kroz funkciju predsjednice i zamjenice predsjednika/ predsjednice navedenih upravljačkih organa. Bitno je naglasiti da su rezultati istraživanja spolne zastupljenosti u upravljačkim pozicijama kod 148 poduzeća provedena nad 8 članica/članova upravnih odbora, 370 članica/članova uprava te 552 članice/člana nadzornog odbora. Dobiveni rezultati istraživanja o spolnoj zastupljenosti u upravljačkim pozicijama istraživanih poduzeća prikazani su u tablici 2.

Tablica 2. Spolna zastupljenost u upravljačkim pozicijama kod 148 istraživanih velikih poduzeća iznad (poduzeća iznad 600 zaposlenika)

\begin{tabular}{|c|c|c|c|c|c|c|c|c|}
\hline \multicolumn{2}{|c|}{$\begin{array}{l}\text { UPRAVNI } \\
\text { ODBOR }\end{array}$} & \multirow[b]{2}{*}{ UKUPNO } & \multicolumn{2}{|c|}{$\begin{array}{c}\text { UPRAVA } \\
\text { DRUŠTVA }\end{array}$} & \multirow[b]{2}{*}{ UKUPNO } & \multicolumn{2}{|c|}{$\begin{array}{c}\text { NADZORNI } \\
\text { ODBOR }\end{array}$} & \multirow[b]{2}{*}{ UKUPNO } \\
\hline Muško & Žensko & & Muško & Žensko & & Muško & Žensko & \\
\hline 7 & 1 & 8 & 319 & 51 & 370 & 423 & 129 & 552 \\
\hline $87,50 \%$ & $12,50 \%$ & $100,00 \%$ & $86,22 \%$ & $13,78 \%$ & $100,00 \%$ & $76,63 \%$ & $23,37 \%$ & $100,00 \%$ \\
\hline
\end{tabular}

Kao što je vidljivo iz tablice 2, kod poduzeća koja imaju jednorazinski model upravljanja kroz upravni odbor zastupljenost žena je na razini 12,5 \%, dok je zastupljenost muškaraca od 87,5 \%. Bitno je naglasiti da je zastupljenost žena u ovom modelu upravljanja isključivo samo kroz članstvo. Kod velikih poduzeća jednorazinski model upravljanja poduzeća putem upravnog odbora imaju 2 poduzeća. $S$ druge strane, rezultati istraživanja su potvrdili da ipak najveći broj poduzeća (146) primjenjuje dvorazinski model upravljanja koristeći upravljačke organe poput uprave društva i nadzornog odbora. Kao što je prethodno navedeno, rezultati istraživanja kod ovog modela upravljanja su pokazali da u upravama društva ima ukupno 370 članova/članica. Zastupljenost žena u upravama tih poduzeća je na razini 13,78 \% (51), a muškaraca 86,22 \% (319). Ovdje je bitno napomenuti da od 51 žene u upravi samo njih 7 ili $13,72 \%$ se nalaze na funkciji predsjednice uprave, dok se preostali broj odnosi na članstvo u upravama društava. Nadalje, što se tiče zastupljenosti u nadzornim odborima, rezultati istraživanja su pokazali da ima ukupno 552 člana/članice. Zastupljenost žena je na razini 23,37 \% (129), a muškaraca 76,63 \% (423). Detaljnije, od ukupnog 
broja žena u nadzornim odborima (129), njih 14 ili 10,85 \% imaju funkciju predsjednice nadzornog odbora, dok 27 ili 20,93\% se nalaze na funkciji zamjenice predsjednice/predsjednika nadzornog odbora. Kod ukupno analiziranih 148 poduzeća zaposleno je 224024 zaposlenika.

Nakon detaljne analize spolne zastupljenosti u upravljačkim pozicijama nad istraživanim poduzećima, u nastavku rada prikazat će se rezultati istraživanja u svrhu opovrgavanja ili dokazivanja temeljne hipoteze rada. Primjenom Mann Whitney-eva testa utvrdit će se postoji li statistički značajna razlika na razini od $5 \%$ između profitabilnosti i spolne zastupljenosti u upravljačkim pozicijama kod velikih poduzeća u Republici Hrvatskoj. Obradom prikupljenih podataka utvrdit će se:

- postoji li statistički značajna razlika između zastupljenosti i nezastupljenosti žena u upravama istraživanih poduzeća u odnosu na profitabilnost poslovanja,

- postoji li statistički značajna razlika između zastupljenosti i nezastupljenosti žena u nadzornim odborima istraživanih poduzeća u odnosu na profitabilnost poslovanja,

- postoji li statistički značajna razlika između zastupljenosti jedne žene i više od jedne žene u upravama istraživanih poduzeća u odnosu na profitabilnost poslovanja, te

- postoji li statistički značajna razlika između zastupljenosti jedne žene i više od jedne žene u nadzornim odborima istraživanih poduzeća u odnosu na profitabilnost poslovanja.

Istraživanje je provedeno u poduzećima koja primjenjuju dvorazinski model upravljanja jer je obradom podataka utvrđeno da od 148 istraživanih poduzeća samo 2 poduzeća primjenjuju jednorazinski model upravljanja putem upravnog odbora što nije dovoljno za provođenje statističke značajnosti rezultata istraživanja. $U$ ovom radu najprije će se ispitati postojanost statistički značajne razlike između uprava društava u kojima su žene zastupljene i u kojima žene nisu zastupljene u odnosu na profitabilnost poslovanja poduzeća. Dobiveni rezultati istraživanja prikazani su u tablici 3.

Tablica 3. Ispitivanje statističke značajnosti između zastupljenosti i nezastupljenosti žena u upravama istraživanih poduzeća u odnosu na profitabilnost poslovanja

\begin{tabular}{|c|c|c|c|c|}
\hline \multirow{2}{*}{$\begin{array}{c}\text { SPOLNA } \\
\text { ZASTUPLJENOST }\end{array}$} & PROSJEČNA PROFITABILNOST & \multirow{2}{*}{$\begin{array}{c}\text { BROJ } \\
\text { EODITDA }\end{array}$} & $\begin{array}{c}\text { NETO PROFITNA } \\
\text { MARŽA }\end{array}$ & $\begin{array}{c}\text { UDIO } \\
\text { PODUZĆA }\end{array}$ \\
\hline BEZ ŽENA & $10,15 \%$ & $2,80 \%$ & 112 & 75,67 \\
\hline SA ŽENAMA & $11,46 \%$ & $3,14 \%$ & 36 & 24,33 \\
\hline UKUPNO & - & - & 148 & 100 \\
\hline Statistička značajnost $(p)$ & 0,69 & 0,74 & - & - \\
\hline
\end{tabular}

Iz tablice 3 vidljivo je postoji 112 (75,67 \%) poduzeća u kojima žene nisu zastupljene u upravama društava, dok je kod 36 (24,33 \%) poduzeća postoji zastupljenost žena u upravama društava. Poduzeća su prosječnu profitabilnost mjerenu pokazateljem EBITDA bez zastupljenost žena u upravama ostvarila na razini od $10,15 \%$, a poduzeća s zastupljenosti žena u upravama na razini 
od 11,46 \%. Budući da se prema dobivenoj vrijednosti pokazatelja EBITDA može zaključiti da su poduzeća s zastupljenosti žena u upravama društava ostvarila veću prosječnu profitabilnost od poduzeća bez zastupljenosti žena u upravama, ovaj rezultat se ne može statistički potvrditi na razni od $5 \%(p=0,69 ; p>0,05)$. S druge strane, poduzeća s zastupljenosti žena u upravama društava su ostvarila prosječnu profitabilnost mjerenu neto profitnom maržom na razini od $3,14 \%$, a poduzeća bez zastupljenosti žena u upravama na razini od $2,80 \%$. lako se prema dobivenoj vrijednosti neto profitne marže može zaključiti da su poduzeća s zastupljenosti žena u upravama društava ostvarila veću prosječnu profitabilnost od poduzeća bez zastupljenosti žena, ovaj rezultat se ne može statistički potvrditi na razni od $5 \%(p=0,74 ; p>0,05)$.

U nastavku ovog rada ispitat će se postojanost statistički značajne razlike između zastupljenosti i nezastupljenosti žena u nadzornim odborima istraživanih poduzeća u odnosu na profitabilnost poslovanja. Rezultati takvog istraživanja prikazani su u tablici 4.

Tablica 4. Ispitivanje statističke značajnosti između zastupljenosti i nezastupljenosti žena u nadzornim odborima istraživanih poduzeća u odnosu na profitabilnost poslovanja

\begin{tabular}{|c|c|c|c|c|}
\hline \multirow{2}{*}{$\begin{array}{c}\text { SPOLNA } \\
\text { ZASTUPLJENOST }\end{array}$} & PROSJEČNA PROFITABILNOST & \multirow{2}{*}{$\begin{array}{c}\text { BROJ } \\
\text { PODUZEĆA }\end{array}$} & \begin{tabular}{c} 
UDIO \\
\cline { 2 - 3 }
\end{tabular} & $\begin{array}{c}\text { NETO PROFITNA } \\
\text { MARŽA }\end{array}$ \\
\hline BEZ ŽENA & $9,67 \%$ & $2,80 \%$ & 72 & 48,65 \\
\hline SA ŽENAMA & $11,07 \%$ & $2,96 \%$ & 76 & 51,35 \\
\hline UKUPNO & - & - & 148 & 100 \\
\hline Statistička značajnost $(p)$ & 0,31 & 0,62 & - & \\
\hline
\end{tabular}

Iz tablice 4 može se zaključiti da postoji 72 (48,65 \%) poduzeća kod kojih žene nisu zastupljene u nadzornim odborima, dok je kod 76 (51,35 \%) poduzeća postoji zastupljenost žena u nadzornim odborima. Poduzeća su prosječnu profitabilnost mjerenu pokazateljem EBITDA bez zastupljenosti žena u nadzornim odborima ostvarila na razini od $9,67 \%$, a poduzeća s zastupljenosti žena $u$ nadzornim odborima na razini od $11,07 \%$. Prema dobivenoj vrijednosti pokazatelja EBITDA može se zaključiti da su poduzeća s zastupljenosti žena u nadzornim odborima ostvarila veću prosječnu profitabilnost od poduzeća bez zastupljenosti žena u nadzornim odborima, ali se rezultat ne može statistički potvrditi na razni od $5 \%(p=0,31 ; p>0,05)$. S druge strane, poduzeća s zastupljenosti žena u nadzornim odborima su ostvarila prosječnu profitabilnost mjerenu neto profitnom maržom na razini od 2,96 \%, a poduzeća bez zastupljenosti žena na razini od 2,80\%. Temeljem prethodno dobivenih rezultata istraživanja može zaključiti da su poduzeća s zastupljenosti žena u nadzornim odborima ostvarila veću prosječnu profitabilnost od poduzeća bez zastupljenosti žena u nadzornim odborima. Ovaj rezultat se ne može statistički potvrditi na razni od $5 \%$ ( $p=0,62$; $p>0,05)$.

Nakon ispitivanja statističke značajnosti između poduzeća koja nemaju zastupljene žene u odnosu na poduzeća koja imaju zastupljene žene u upravama društava i nadzornim odborima uzimajući 
u obzir profitabilnost poslovanja poduzeća, u nastavku rada ispitat će se statistička značajnost između zastupljenosti jedne žene i više od jedne žene u upravama društava i nadzornim odborima u odnosu na profitabilnost poduzeća. Stoga su u tablici 5 najprije prikazani rezultati istraživanja statističke značajnosti između zastupljenosti jedne žene i više od jedne žene u upravama istraživanih poduzeća u odnosu na profitabilnost poslovanja.

Iz tablice 5 vidi se da postoji 25 (69,44\%) istraživanih poduzeća u kojima je zastupljena jedna žena u upravama, dok je kod 11 (30,56 \%) poduzeća postoji zastupljenost više od jedne žena u upravama. Poduzeća u kojima je zastupljena jedna žena u upravama su ostvarila prosječnu profitabilnost putem EBITDA od $11,03 \%$, a poduzeća s zastupljenosti više od jedne žene u upravama društava na razini od $11,40 \%$. S obzirom na dobivene vrijednosti pokazatelja EBITDA i statističku značajnost testa može se zaključiti da su poduzeća s zastupljenosti više od jedne žene u upravama društava ostvarila veću prosječnu profitabilnost od poduzeća s zastupljenosti samo jedne žene u upravama društava čime se ovaj rezultat ne može statistički potvrditi na razni od $5 \%(p=0,77 ; p>0,05)$.

Tablica 5. Ispitivanje statističke značajnosti između zastupljenosti jedne žene i više od jedne žene u upravama istraživanih poduzeća u odnosu na profitabilnost poslovanja

\begin{tabular}{|c|c|c|c|c|}
\hline \multirow{2}{*}{$\begin{array}{c}\text { SPOLNA } \\
\text { ZASTUPLJENOST }\end{array}$} & \multicolumn{2}{|c|}{ PROSJEČNA PROFITABILNOST } & \multirow{2}{*}{$\begin{array}{c}\text { BROJ } \\
\text { PODUZEĆA }\end{array}$} & \multirow{2}{*}{$\begin{array}{c}\text { UDIO } \\
(\%)\end{array}$} \\
\hline & EBITDA & $\begin{array}{c}\text { NETO PROFITNA } \\
\text { MARŽA }\end{array}$ & & \\
\hline 1 ŽENA & $11,03 \%$ & $3,04 \%$ & 25 & 69,44 \\
\hline$>1$ ŽENA & $11,40 \%$ & $3,37 \%$ & 11 & 30,56 \\
\hline UKUPNO & - & - & 36 & 100 \\
\hline Statistička značajnost $(p)$ & 0,77 & 0,79 & - & \\
\hline
\end{tabular}

S druge strane, poduzeća s zastupljenosti više od jedne žene u upravama društava su ostvarila prosječnu profitabilnost mjerenu neto profitnom maržom od $3,37 \%$, a poduzeća s zastupljenosti jedne žene u upravama na razini od $3,04 \%$. Budući da se prema dobivenoj vrijednosti neto profitne marže može zaključiti da su poduzeća s zastupljenosti više od jedne žene u upravama ostvarila veću prosječnu profitabilnost od poduzeća s zastupljenosti samo jedne žene u upravama društava, dobiveni rezultat se ne može statistički potvrditi na razni od $5 \%(p=0,79 ; p>0,05)$.

Nadalje, nakon ispitivanja statističke značajnosti između zastupljenosti jedne žene i više od jedne žene u upravama istraživanih poduzeća u odnosu na profitabilnost poslovanja, u tablici 6 prikazani su rezultati ispitivanja statističke značajnosti između zastupljenosti jedne žene i više od jedne žene u nadzornim odborima istraživanih poduzeća u odnosu na profitabilnost poslovanja. 
Tablica 6. Ispitivanje statističke značajnosti između zastupljenosti jedne žene i više od jedne žene u nadzornim odborima istraživanih poduzeća u odnosu na profitabilnost poslovanja

\begin{tabular}{|c|c|c|c|c|}
\hline \multirow{2}{*}{$\begin{array}{c}\text { SPOLNA } \\
\text { ZASTUPLJENOST }\end{array}$} & \multicolumn{2}{|c|}{ PROSJEČNA PROFITABILNOST } & \multirow{2}{*}{$\begin{array}{c}\text { BROJ } \\
\text { PODUZEĆA }\end{array}$} & \multirow{2}{*}{$\begin{array}{l}\text { UDIO } \\
(\%)\end{array}$} \\
\hline & EBITDA & $\begin{array}{c}\text { NETO PROFITNA } \\
\text { MARŽA }\end{array}$ & & \\
\hline 1 ŽENA & $9,91 \%$ & $1,90 \%$ & 39 & 51,32 \\
\hline$>1$ ŽENA & $12,29 \%$ & $4,52 \%$ & 37 & 48,68 \\
\hline UKUPNO & - & - & 76 & 100 \\
\hline Statistička značajnost $(p)$ & 0,66 & 0,42 & - & \\
\hline
\end{tabular}

Izvor: obrada autora

Tablica 6 pokazuje da postoji 39 (51,32 \%) istraživanih poduzeća u kojima je zastupljena jedna žena u nadzornim odborima, dok je kod 37 (48,68 \%) poduzeća postoji zastupljenost više od jedne žena u nadzornim odborima. Poduzeća u kojima je zastupljena jedna žena u nadzornim odborima su ostvarila prosječnu profitabilnost putem EBITDA od 12,29 \%, a poduzeća s zastupljenosti više od jedne žene u nadzornim odborima na razini od 9,91\%. Prema dobivenoj vrijednosti pokazatelja EBITDA može se zaključiti da su poduzeća s zastupljenosti više od jedne žene u nadzornim odborima ostvarila veću prosječnu profitabilnost od poduzeća s zastupljenosti samo jedne žene u nadzornim odborima. Ovako dobiveni rezultat istraživanja se ne može statistički potvrditi na razni od $5 \%(p=0,66 ; p>0,05)$. S druge strane, poduzeća s zastupljenosti više od jedne žene u nadzornim odborima su ostvarila prosječnu profitabilnost mjerenu neto profitnom maržom od $4,52 \%$, a poduzeća s zastupljenosti jedne žene u nadzornim odborima na razini od 1,90\%. Dobivene vrijednosti neto profitne marže pokazuju da su poduzeća s zastupljenosti više od jedne žene u nadzornim odborima ostvarila veću prosječnu profitabilnost od poduzeća s zastupljenosti samo jedne žene u nadzornim odborima. Ovaj rezultat se ne može statistički potvrditi na razni od $5 \%(p=0,42 ; p>0,05)$.

Budući da su rezultati istraživanja potvrdili da su istraživana poduzeća u čijim su upravama i nadzornim odborima zastupljene žene ostvarila veću prosječnu profitabilnost od poduzeća gdje u upravama i nadzornim odborima nisu zastupljene žene, ovako dobiveni rezultati se ne mogu statistički potvrditi jer je dobivena statistička značajnost testa veća od $5 \%(p>0,05)$. S druge strane, dobiveni rezultati istraživanja su također pokazali da su istraživana poduzeća u čijim je upravama i nadzornim odborima zastupljeno više od jedne žene ostvarila veću prosječnu profitabilnost od poduzeća gdje je upravama i nadzornim odborima zastupljena samo jedna žena. Međutim, ovako dobiveni rezultat se ne može statistički potvrditi jer je, i u ovom slučaju, dobivena statistička značajnost testa veća od $5 \%(p>0,05)$. Slijedom prethodno analiziranih rezultata istraživanja može se zaključiti da temeljna hipoteza rada nije potvrđena. Razlog statističkog neprihvaćanja temeljne hipoteze rada je u približno dobivenim vrijednostima prosječne profitabilnosti u odnosu na spolnu zastupljenost u upravljačkim pozicijama kod istraživanih poduzeća u primijenjenim modalitetima istraživanja ovog rada. 


\section{PREPORUKE ZA BUDUĆA ISTRAŽIVANJA}

Utjecaj spolne zastupljenosti u upravljačkim pozicijama na profitabilnost velikih poduzeća u Republici Hrvatskoj je veoma aktualna tema koja sve više potiče raspravu o ravnopravnosti spolova. Istraživanja na ovu temu su brojna u drugim državama svijeta, dok u Republici Hrvatskoj postoje određena istraživanja koja su uvelike manja nego u drugim zemljama Europske unije. Najintenzivnije ovu temu objašnjava Pravobraniteljica za ravnopravnost spolova u svojim godišnjim izvješćima koja su prikazana u ovom radu. Budući da su istraživanja na ovu temu u Republici Hrvatskoj na samom početku razvoja, postoji sve veća potreba za provedbu ovog tipa istraživanja u budućnosti.

Najprije, utjecaj spolne zastupljenosti u upravljačkim pozicijama na rezultate poslovanja poduzeća u Republici Hrvatskoj moguće je dodatno provesti u privatnom sektoru. Budući da je u ovom radu napravljeno istraživanja nad 148 velikih poduzeća iznad 600 zaposlenika, sljedeće istraživanje moguće je provesti nad ostatak 300 velikih poduzeća koji ukupno zapošljavaju 109110 zaposlenika. Istraživanje može ići u smjeru ispitivanje utjecaja spolne zastupljenosti u upravljačkim pozicijama na profitabilnost, likvidnost, zaduženosti i tržišnu poziciju na pozicioniranim tržištima. U ovom istraživanju se može ići s pretpostavkom da veća zastupljenost žena u upravljačkim pozicijama uzroku veću profitabilnost, manju zaduženost i bolju tržišnu poziciju na pozicioniranim tržištima.

S druge strane, utjecaj spolne zastupljenosti u upravljačkim pozicijama na rezultate poslovanja poduzeća u Republici Hrvatskoj također je moguće provesti i u javnoj upravi. Ovo istraživanje se može primijeniti na institucije u javnoj upravi analizirajući spolnu zastupljenost na čelnim pozicijama i u upravnim vijećima na efikasnost poslovanja. Tu spadaju ministarstva, tijela državne uprave, državni uredi, agencije, županije, općine i gradovi te institucije u kojima su isti osnivači. Uspješnost poslovanja kod javnih institucija je moguće utvrditi putem vremenske efikasnosti obrade zahtjeva zaprimljenog od strane stranke i postotnog izvršenja postavljenih ciljeva u jednoj proračunskoj godini. U ovom istraživanju se može ići s pretpostavkom da veća zastupljenost žena u upravljačkim pozicijama u javnoj upravi uzrokuje kraće vrijeme obrade zahtjeva zaprimljenog od strane stranke i većem postotku izvršenja postavljenih ciljeva u proračunskoj godini.

\section{ZAKLJUČAK}

Spolna zastupljenost u upravljačkim pozicijama poduzeća je veoma zanimljiva tema u posljednje vrijeme. Na ovu temu su napravljena brojna istraživanja u svijetu, a prvi pomaci su se dogodili i u Republici Hrvatskoj. Stoga je svaka provedba istraživanja na ovu temu važan napredak u znanstvenoj i stručnoj literaturi u Republici Hrvatskoj čime se doprinosi stalnom upoznavanju stanja spolne zastupljenosti u upravljačkim pozicijama poduzeća i stvaranju percepcije da je nužno da se na upravljačke pozicije imenuju sposobne i stručne osobe bez obzira na spol.

Upravo zbog veoma manjeg broja provedenih istraživanja na temu spolne zastupljenosti u upravljačkim pozicijama, javila se potreba za provođenjem ovog istraživanja. Prilikom provedbe istraživanja analizirana su velika poduzeća u Republici Hrvatskoj prema kriteriju broja zaposlenika. Točnije, istraživanje utjecaja spolne zastupljenosti u upravljačkim pozicijama na profitabilnost provedeno je nad 148 velikih poduzeća iznad 600 zaposlenika. Budući da su samo dva poduzeća imala upravljanje putem jednorazinskog modela primjenom upravnog odbora, istraživanje nije 
provedeno kod ove skupine poduzeća već samo kod poduzeća koja su imala dvorazinski model upravljanja putem uprave društva i nadzornog odbora

Dobiveni rezultati istraživanja pokazali su da su istraživana poduzeća u čijim su upravama i nadzornim odborima zastupljene žene ostvarila veću prosječnu profitabilnost od poduzeća gdje u upravama i nadzornim odborima nisu zastupljene žene. S druge strane, rezultati istraživanja su također pokazali da su istraživana poduzeća u čijim je upravama i nadzornim odborima zastupljeno više od jedne žene ostvarila veću prosječnu profitabilnost od poduzeća gdje u upravama i nadzornim odborima zastupljena jedna žena. Budući da su se u obje grupe istraživanja dobiveni rezultati koji odgovaraju temeljnoj hipotezi rada, vrijednosti dobivenih statističkih značajnosti potvrđuju ne postojanje statistički značajne razlike između dobivenih rezultata temeljem čega se zaključuje da temeljna hipoteza rada nije potvrđena.

\section{LITERATURA}

Buble, M., Osnove menadžmenta, Sinergija nakladništvo d. o. o., Zagreb, 2006.

Izvještaj o radu Pravobraniteljice za ravnopravnost spolova za 2017.godinu (https://www.prs.hr/index.php/izvjesca/2017, 21. 7. 2019.)

Izvještaj o radu Pravobraniteljice za ravnopravnost spolova za 2015. godinu (https://www.prs.hr/index.php/izvjesca/2015, 21. 7. 2019.)

Izvještaj o radu Pravobraniteljice za ravnopravnost spolova za 2014. godinu (https://www.prs.hr/index.php/izvjesca/2014, 10. 7. 2019.)

Izvještaj o radu Pravobraniteljice za ravnopravnost spolova za 2011. godinu (https://www.prs.hr/index.php/izvjesca/ izvjesce-2011, 15. 7. 2019.)

McKinsey \& Company (2007) Women Matter: Gender diversity, a corporate performance driver, 2007. (https://www. mckinsey.com/business-functions/organization/our-insights/gender-diversity-a-corporate-performance-driver, 30. 7. 2019.)

Mkhize, M., Msweli, P., The impact of female business leaders on the performance of listed companies in South Africa, Journal of Economic and Management Sciences, 14 (1), 2011., p. 1-7.(http://www.scielo.org.za/scielo.php?script=sci_ arttext\&pid=S2222-34362011000100001, 14. 8. 2019.)

Nidegon Višnjić, S., et. al., Stavovi i percepcije žena na rukovodećim pozicijama o njihovom položaju na radnom mjestu, Ekonomska misao i praksa, 27 (1), 2018., p-287-313. (https://hrcak.srce.hr/index.php?show=clanak\&id_clanak_ jezik=297770, 13. 7. 2019.)

Posarić, N., et. al., Analiza zastupljenosti žena na upravljačkim pozicijama u hrvatskim poduzećima i njihov utjecaj na uspješnost poslovanja, Ekonomski pregled, 70 (2), 2019., p. 259-275. (https://hrcak.srce.hr/index. php?show=clanak\&id_clanak_jezik=319386, 12. 7. 2019.)

Soldat, M., Žene u menadžmentu s osvrtom na primjere, Završni rad, Međimursko veleučilište u Čakovcu, Čakovec, 2018. (https://repozitorij.mev.hr/islandora/object/mev\%3A802/datastream/PDF/view, 22. 7. 2019.)

Strelcova, J., Does Gender Matter? A Comparative Study of Performance of American CEOs, The Leonard N. Stern School of Business Glucksman Institute for Research in Securities Markets, 2014. (https://archive.nyu.edu/ bitstream/2451/26400/2/FIN-05-001.pdf, 1. 8. 2019.)

Tacheva, S., Huse, M., Women directors and board task performance: mediating and moderating effects of board working style, EURAM meeting, 2006. (https://www.boeckler.de/pdf/v_2006_03_30_huse2_f5.pdf, 3. 8. 2019.) 
Ž. Mateljak: Utjecaj spolne zastupljenosti u upravljačkim pozicijama na profitabilnost velikih...

Zbornik Veleučilišta u Rijeci, Vol. 8 (2020), No. 1, pp. 1-17

Veštić, S., Zakon o ravnopravnosti spolova - razlozi donošenja i institucionalni mehanizmi osiguranja provedbe, Zbornik radova Veleučilišta u Šibeniku, 3 (4), 2017. (https://hrcak.srce.hr/184560, 13. 8. 2019.)

Zakon o ravnopravnosti spolova (NN, 82/08)

Zakon o ravnopravnosti spolova (NN, 69/17)

Zakon o ravnopravnosti spolova (NN, 116/03)

Zakon o računovodstvu (NN, 116/18)

Zakon o sustavu državne uprave (NN, 66/19)

Zakon o državnim službenicima (NN, 61/17)

https://lider.media/lider-trend/samo-202-godine-su-potrebne-da-se-izjednaciekonomski-jaz-izmedu-zena-i muskaraca/, (4. 7. 2019.)

https://www.credit-suisse.com/about-us-news/en/articles/media-releases/csri-gender3000-201609. html?t=183_0.5562689241064736, (21. 7. 2019.)

https://ec.europa.eu/info/policies/justice-and-fundamental-rights/gender equality, (21. 7. 2019.)

https://www.catalyst.org/wpcontent/uploads/2019/01/The_Bottom_Line_Corporate_Performance_and_Womens_ Representation_on_Boards.pdf, (21. 7. 2019.) 


\title{
IMPACT OF GENDER REPRESENTATION IN MANAGEMENT POSITIONS ON THE PROFITABILITY OF LARGE ENTERPRISES IN THE REPUBLIC OF CROATIA
}

\section{Željko Mateljak}

PhD, Assistant Professor, Faculty of Economics, Business and Tourism, University of Split, Cvite Fiskovića 5, 21000 Split, Croatia; e-mail: zeljko.mateljak@efst.hr

\begin{abstract}
Each company endeavors to organize its operations with an appropriate management model implemented through governing bodies in relation to the current business environment. The basic governing bodies of many companies are the General Board, the Board of Directors and the Supervisory Board. The emphasis in this paper was on the analysis of gender representation in managerial positions, that is, whether there is a difference in the profitability of large enterprises in the Republic of Croatia compared to the representation of women and men in managerial positions. The subject of this paper is to recognize the importance of gender representation in management positions in large enterprises in the Republic of Croatia. The problem of this paper is determine how gender representation in management positions contributes to greater profitability in large enterprises in the Republic of Croatia. The basic hypothesis of the paper is that there is a statistically significant difference between gender representation in management positions and the profitability of large enterprises in the Republic of Croatia. The survey is conducted on 148 large companies with over 600 employees in the Republic of Croatia. The results of the research showed that there is no statistically significant difference between profitability and gender representation in management positions in large enterprises with more than 600 employees in the Republic of Croatia. This research is the basis for further research on this topic in the Republic of Croatia.
\end{abstract}

Key words: gender representation, management positions, large enterprises, profitability 